\title{
SOCIALIZATION OF THE RIGHT ELECTRIC USAGE TO PREVENT HAZARDOUS FIRE IN TUGU SELATAN VILLAGE, KOJA, NORTH JAKARTA
}

\author{
Rummi Sirait, Nifty Fath, Eka Purwa Laksana \\ Universitas Budi Luhur, Indonesia \\ rummi.sirait@budiluhur.ac.id
}

\begin{abstract}
The use of electrical equipment that is not in accordance with the standards established by SNI (Standar Nasional Indonesia) and the installation of electrical equipment that is not in accordance with the provisions are still often found in people's homes, so that the threat of electric fire hazards will be possible. Data from the recapitulation of fire incidents in DKI Jakarta Province in 2018 revealed that the biggest cause of fire was due to electrical short circuit, as many as 494 fire incidents occurred in a total of 1667 residences. This is quite alarming because many of the fires are caused by the low quality and installation of cables in most people's homes and residents do not understand the dangers of using inappropriate electrical energy. To participate in assisting the government in conducting socialization about the right electricity usage to prevent fires, the PPM activities in the form of socialization and direct assistance to residents' homes. The purpose of this activity is so that in the future residents of the Tugu Selatan Village of North Jakarta are more concerned about the electrical installations and the electrical equipment they use by following with specified standards. This activity is very useful for the residents, proven by their enthusiasm in participating in the extension program with questions about the correct use of electrical energy and people's curiosity in knowing how to save electricity usage at home and calculate the cost of using electricity in their homes.
\end{abstract}

Keywords: Short Circuit, Electricity, SNI, Electrical Hazard

\section{INTRODUCTION}

Today's modern life has been fully related to electrical energy, but there are still many users/consumers of electricity who are still unfamiliar with this one thing. Mainly are electricity users in residential areas, which incidentally are the users with the largest number. With the development of increasingly modern technology, electricity has a very important role in life and the industrial world. Beside electricity can cause accidents for humans and the onset of fire and disruption of the production process. Therefore, it is necessary to avoid the danger sources starting from the planning, installation and usage stages through electrical installations. The increasing need for electricity to make ends meet is a reason for the need for good and safe electrical installations. Without causing various hazards caused by electricity, including electric shock, thermal effects, the influence of electromagnetic waves, radiation and other hazards caused by electricity.

The main problem in studying electricity is that it is invisible and cannot be touched, even we don't want to feel it. We know there is electricity after seeing the consequences, such as lights on, fans spinning, and the radio sounds. There are three dangers caused by electricity, namely electric shock, heat or fire, and explosion. An electric shock or shock will be felt if an electric current passes through our body. Usually the current will begin to be felt if the current flowing more than $5 \mathrm{~mA}$. At small currents, current will only cause tingling or lose the ability to control the hand. At large currents, electric current can burn our skin and flesh

Electricity safety is any effort or steps to secure electricity supply installations and to secure electricity users to realize reliable and safe conditions for the installation and safe conditions from danger to humans and other living things, as well as environmentally friendly conditions, around electric power installations.

Based on data from the Fire and Rescue Service, the number of fires in 2018 increased from the previous year. Judging from the fire data from January to April 3, 2018, the number of fires in Jakarta has reached 873 cases. The biggest cause of fire was due to electrical short circuit, there were 494 fire incidents that occurred in a total of 1667 homes. Fires that occur due to electricity generally come from poor installations, use of materials that are not up to standard, to the use of uncontrolled electrical equipment, resulting in overheating and resulting in fires. A simple example of an electrical accident is the accumulation of too many stekker as shown in picture 1 . This is quite alarming because many of the fires are caused by the low quality and installation of cables in most people's homes. 


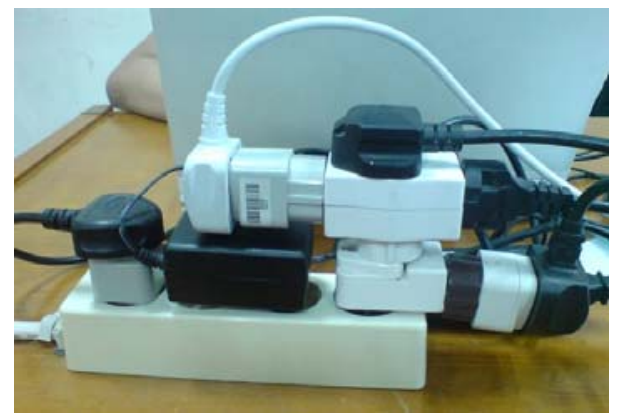

Picture 1. Piled up too many stekker

Lack of public understanding of the importance of safety in daily activities concerning the use and utilization of electricity, this socialization activity is carried out to educate the public about the importance of understanding the use of electricity by providing material and understanding to the public about the importance of using electricity in accordance with standards SNI to reduce the danger of fire due to electricity.

\section{GENERAL DESCRIPTION OF THE TARGET COMMUNITY Profile of Target Communities}

Geographically, Tugu Selatan Village has an area of $268 \mathrm{Ha}$ (based on the Decree of the Governor of DKI Jakarta Number: 1251 of 1986 concerning the division of Tugu Village into Tugu Utara Village and Tugu Selatan Village in the Koja District of North Jakarta Municipality with the following boundaries: North is bordered by Plumpang Semper Street, Tugu Utara Village, in the east by Cakung Lama River, West Semper Village, in the South by Batik Dam, Pegangsaan Dua, and West with Kali Dam Malay River, Rawabadak Selatan Village.

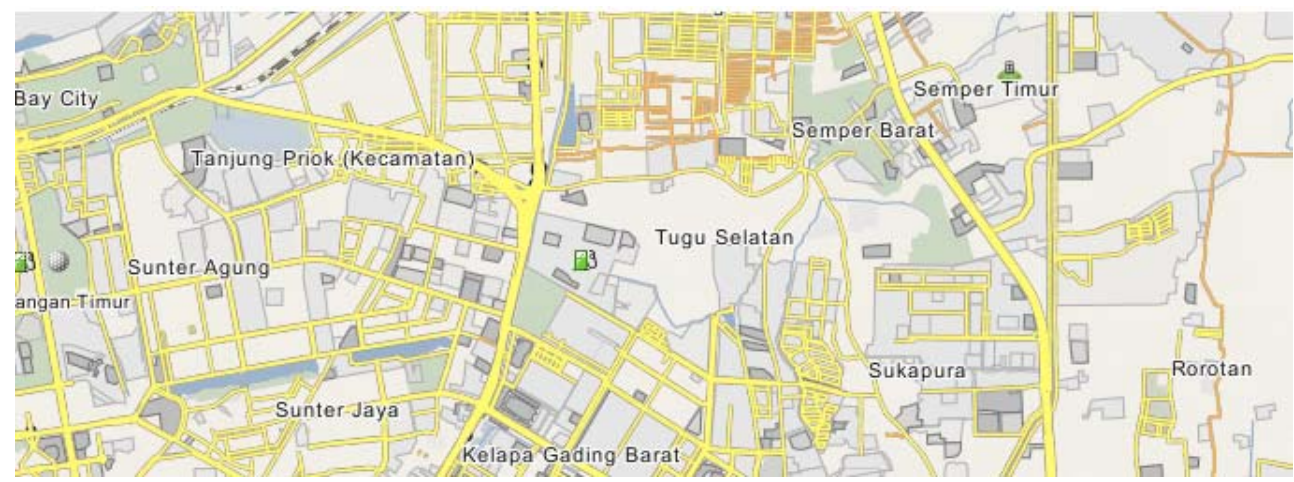

Picture 2. Map of Tugu Selatan

There are 55 slum RWs spread across six sub-districts, namely Penjaringan Sub-district there are $16 \mathrm{RW}$, Cilincing 14 RW, Tanjung Priok nine RW, Pademangan seven RW, Koja six RW and Kelapa Gading three RW. The slum RW variables, namely the level of population density, building layout, construction of residential buildings, building density, ventilation, road conditions, drainage channels, places to defecate, frequency of garbage transportation and public street lighting.
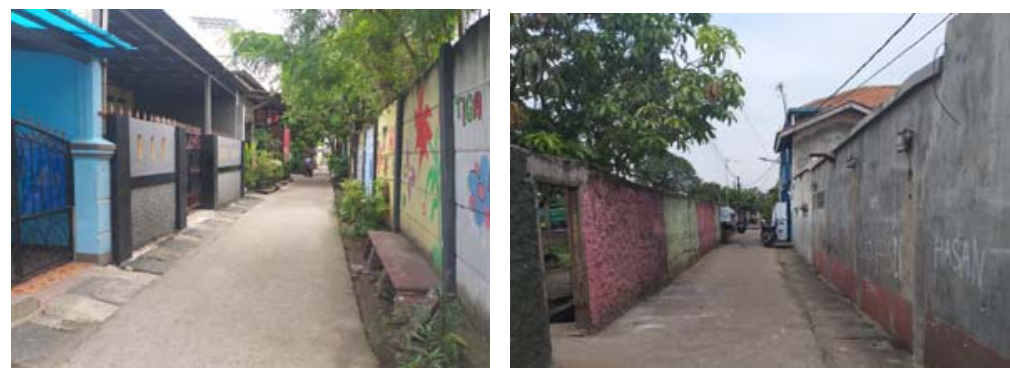

Picture 3. Residents in RT 04 / RW 04 Tugu Selatan 
Residential areas in slums are prone to fire, such as the June 2018 incident in a dense residential area in Tugu Selatan, a fire that burned dozens of homes and resulted in fatalities. From the results of the investigation this fire incident occurred due to a short circuit of electricity in one of the residents 'houses and impacted the houses around the residents' homes. The incident was also due to the lack of understanding of residents in the use of electricity properly so that it can have an impact on the occurrence of fire.

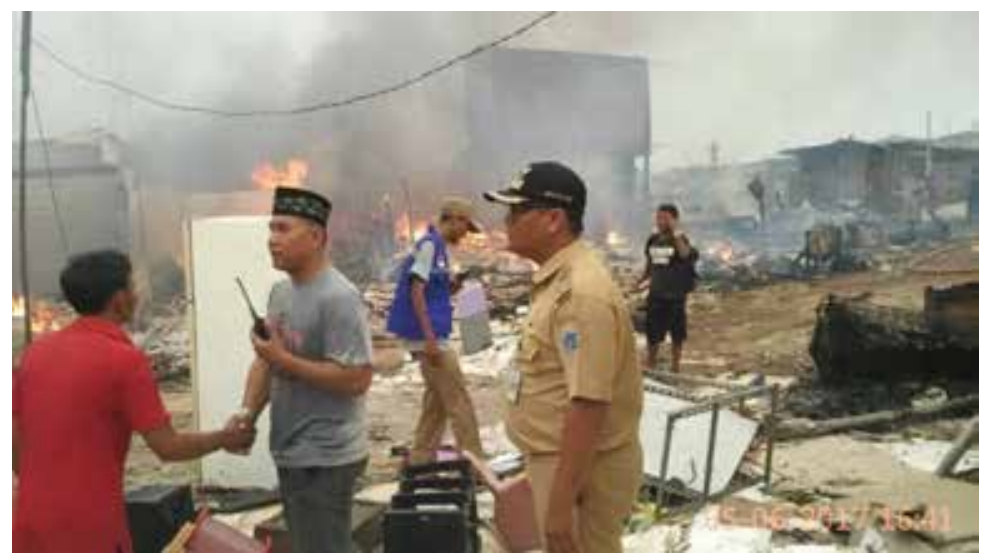

Picture 4. Fire incident in a dense settlement in Tugu

\section{Environmental Conditions RT 04 / RW 04 Tugu Selatan Village}

RW 04 area of Tugu Selatan sub-district is occupied by around 2,000 people living in RW 04 area and spreading over 9 RTs. RW 04 region is a "bowl" or "demographic low soil culture" area, so this makes it a floodsubscribed area. RW 04 residents still use a lot of electrical equipment such as: cables, switches, sockets, plugs that are Non-SNI (Indonesian National Standard) or LMK (Electricity Society Institution) so that the threat of electric fire hazard might threaten the residents. In connection with the RW 04 area is a flood subscriptions, it is very important for residents to know the dangers of electricity when the flood comes one of which is the right electricity installation, so that when there is a flood come the community can take appropriate action so that there are no accidents due to electricity.

Based on data from the Fire and Rescue Service the number of fires in 2018 increased from the previous year. Judging from the fire data from January to April 3, 2018, the number of fires in Jakarta has reached 873 cases. This is quite alarming because many of the fires are caused by the low quality and installation of cables in most people's homes. To participate in assisting the government in conducting counseling about electricity-related fires, an instrument of Community Service activities was arranged in the form of information on the use of electricity and direct assistance to residents' homes, so that future residents of Tugu Selatan Village, North Jakarta, are more concerned about electrical installations and tools. The electricity they use complies with the specified standards.

\section{IMPLEMENTATION METHOD}

The socialization activities of the right electric usage to prevent hazardous fire in RT 04 / RW 04 Tugu Selatan village, Koja District, North Jakarta, through the stages as shown in table 1.

Table 1. Program implementation method

\begin{tabular}{cl}
\hline No. & The activities \\
\hline 1. & Partner location survey to get data on partner needs \\
\hline 2. & Obtaining permits to the local RW and RT for PPM activities \\
\hline 3. & PPM team discussion for the distribution of tasks during the socialization event \\
\hline 3. & Coordination with the local RT and RW to organize this socialization activity \\
\hline 4. & Preparation for Community Service activities at Budi Luhur University : \\
& a. Submission of PPM proposals \\
& b. Preparing extension materials \\
& c. Prepare materials and tools that can be used for extension activities \\
& d. Prepare facilities and infrastructure activities \\
\hline 5. & Implementation of socialization events and mentoring the right electric usage to
\end{tabular}


prevent fire hazards in RT 04 / RW 04 Tugu Selatan Village

6. Evaluate and prepare PPM implementation report

7. Publication

The PPM activity was carried out by a team of lecturers from the Faculty of Engineering, along with students of the Electrical Engineering study program at Budi Luhur University.

\section{RESULTS AND DISCUSSION}

\section{Results}

Community service activities conducted by a team of lecturers and students of the Electrical Engineering Study Program, Faculty of Engineering, Budi Luhur University have been carried out in the residents of RT 04 / RW 04, Tugu Selatan Village, Koja District, North Jakarta. The speech from the residents represented by the head of RW 04, Mr. Awang, was very enthusiastic about the arrival of the PPM team in providing socialization in the form of counseling for its citizens. The counseling theme is about the proper use of electricity and the dangers that can be caused by errors in the use of electricity. The counseling theme that will be conveyed by the FT team is very precise with the existence of RW04 community members in Tugu Selatan Village who still do not understand what the dangers of using electricity are incorrect. Counseling to residents was divided into three sessions.

The first session The implementation of counseling by involving students who worked at PLN to explain about digital KWh meters and analog KWh meters, and standard and non-standard electrical equipment. Residents are shown examples of electrical equipment that complies with SNI or SPLN standards. In the first session, residents were taught about energy saving measures in their daily lives. This was conveyed because of the people's request to be given an explanation of how to save energy, and calculate the electricity bill used every month. PPM Team of Electrical Engineering Lecturers gave some tips to save energy namely turning off the lights when not in use and using energy-saving lamps namely LED lights, do not use washing machines with excessive clothing loads because it will aggravate the washing machine workload, and others. By using energy saving lamps, residents can save on electricity costs. In addition, residents were also reminded to only turn on the lights when needed and choose lamps with power according to their needs. For example, for lighting lamps in bathrooms and on terraces it is sufficient to use low-power lamps while lighting for study lights needs to use bright enough.

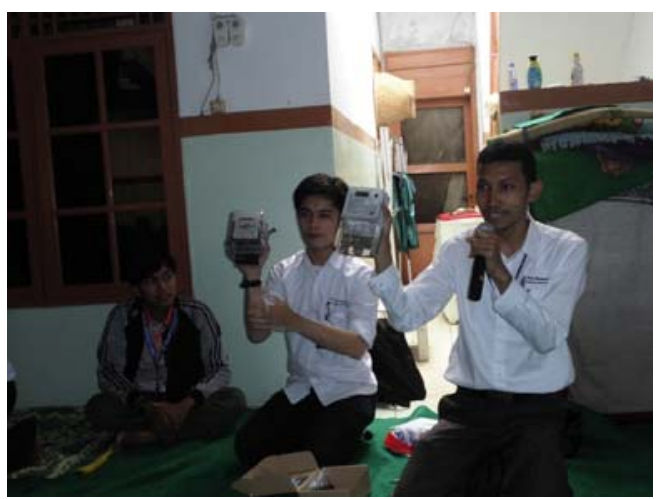

Picture 5. Explanation of digital KWh meters and analog KWh meters

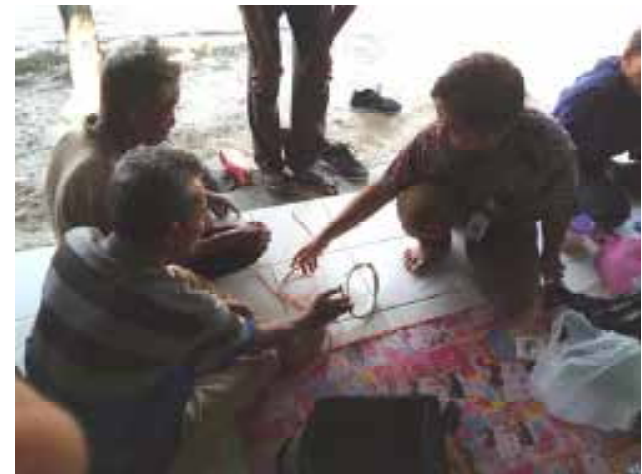

Picture 6. Explanation of standard and non-standard electrical equipment 
The second session was exposure to the danger of fire due to improper use of electricity and things that can be done to prevent accidents and fires due to improper use of electricity. In this session the residents were given an explanation of the electricity network that was owned by PLN and owned by the residents. Daily activities that need attention that seem trivial, but have the potential to cause a fire hazard or other accidents due to errors in the use of electrical equipment that is not in accordance with procedures and standards that have been determined.

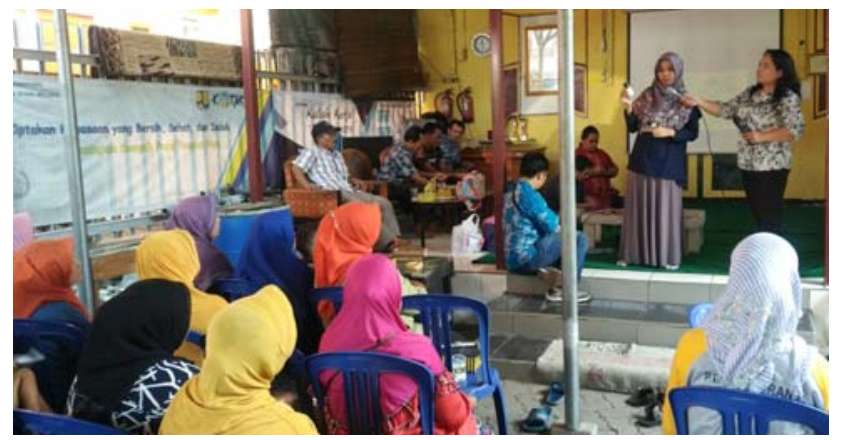

Picture 7. Explanation of causes and tips for preventing fire due to electricity

The third session is a discussion session. In this session participants are welcome to ask questions or input related to the material of the socialization.

The socialization activity was attended by around 40 participants consisting of youth, mothers and local community leaders. Based on the discussion session shows the importance of the socialization event about the right electricity usage and the dangers posed if the community does not use standard electrical equipment. Citizens' curiosity about how to save electricity usage and how to calculate the cost of electricity usage every month shows that the community's interest in this socialization activity is very large.

\section{Discussion}

The PPM activities presented were in the form of:

1. Energy-saving measures, how to calculate the cost of using electricity in accordance with existing equipment in the home and examples of energy-efficient electrical appliances such as LED lights.

2. Presentation of the dangers of fire and accidents due to improper use of electricity, as well as things that can be done to prevent accidents and fires due to improper use of electricity.

3. Discussion and question and answer related to energy-saving measures, the hazards caused by and the things that can be done to prevent fires due to improper use of electricity

\section{CONCLUCION}

PPM activities carried out by the Electrical Engineering PPM Team namely regarding counseling and mentoring the right electric usage to prevent fire hazards in RT 04 / RW 04 Tugu Selatan Village, Koja District, North Jakarta received very high enthusiasm from the community. The community is motivated to use electrical equipment that is energy efficient and in accordance with specified standards. In addition, the public better understands how to use electricity properly, so as to prevent accidents and the danger of fire due to electricity. Therefore, this counseling really needs to be developed and carried out in a sustainable manner so that the community can continue to add insight into electrical energy. 


\section{REFERENCES}

Anonim. 2018. Bahaya Listrik dan Pencegahannya, https://www.tukanglistrik.com/2018/04/bahaya-listrik-danpencegahannya.html, diakses tanggal 17 Desember 2018.

PLN. 2011. Keselamatan Ketenagalistrikan, https://pln24.wordpress.com/materi/pembidangan-2/keselamatanketenagalistrikank2/, diakses tanggal 5 Agustus 2018.

Jakarta Open Data Berbagi Data Untuk Transparansi. 2018. Data Kejadian Bencana Kebakaran di DKI Jakarta Tahun 2018. http://data.jakarta.go.id.

Ign Agung Nugroho. 2019. Cegah Bahaya Kebakaran, ICA Sosialisasikan 'Listrik Andal Rumah Aman'. Wartakotalive https://wartakota.tribunnews.com.

Tribun Kaltim.Co. 2019. Cegah Kebakaran Akibat Korsleting Listrik di Rumah, Perhatikan 6 Hal Ini, https://kaltim.tribunnews.com.

P. Resmi P. D. J. Dinas Komunikasi, Informatika dan Statistik Pemprov DKI Jakarta. 2019. Koja-kecamatan, https://jakarta.go.id.

Y. Rachman. 2019. Instalasi Listrik Buruk Penyebab Jakarta Rentan Kebakaran. https://www.antaranews.com/berita 